$9-1-2016$

\title{
Oil price and inflation in Algeria: A nonlinear ARDL approach
}

Miloud Lacheheb

Universite Putra Malaysia

Abdalla Sirag

Universiti Putra Malaysia

Follow this and additional works at: https://ecommons.luc.edu/meea

\section{Recommended Citation}

Lacheheb, Miloud and Sirag, Abdalla, "Oil price and inflation in Algeria: A nonlinear ARDL approach". Topics in Middle Eastern and North African Economies, electronic journal, 18, 2, Middle East Economic Association and Loyola University Chicago, 2016, http://www.luc.edu/orgs/meea/

This Article is brought to you for free and open access by the Journals and Magazines at Loyola eCommons. It has been accepted for inclusion in Topics in Middle Eastern and North African Economies by an authorized administrator of Loyola eCommons. For more information, please contact ecommons@luc.edu. cc) (i) (2)

This work is licensed under a Creative Commons Attribution-Noncommercial-No Derivative Works 3.0 License. (C) 2016 The Authors 


\title{
Oil price and inflation in Algeria: A nonlinear ARDL approach
}

\author{
Miloud Lacheheb ${ }^{1}$, Abdalla Sirag ${ }^{2}$
}

\begin{abstract}
:
This study examined the relationship between oil price changes and inflation rate in Algeria from 1970 - 2014. The study method that able to capture for asymmetries in the relationship between oil price and inflation known as nonlinear autoregressive distributed lags (NARDL). The estimated model revealed the existence of nonlinear effect of oil price on inflation. Specifically, we found a significant relation between oil price increases and inflation rate, whereas, a significant relation between oil price reduction and the inflation was absent.
\end{abstract}

Keywords: Inflation behavior; Oil price; Asymmetry; Algeria.

JEL Classification: N55, E31, E52

\footnotetext{
${ }^{1}$ Department of Economics, Universite Putra Malaysia, Serdang, Malaysia; Department of Management, Universite Kasdi Merbah, Ouargla, Algeria; Email: miloulach@yahoo.fr

2 Department of Economics, Universiti Putra Malaysia, Serdang, Malaysia
} 


\section{Introduction}

Oil price fluctuations have received both extensive academic and government discussion due to its considerable economic consequences. Oil price increase is considered good news in oil exporting countries and bad news in oil importing countries, the reverse is expected when the oil price decreases. The correlation between oil price shocks and macro-economy is equally probed. Caruth, Hooker, \& Oswald, (1998); Davis \& Altiwanger, (2001); Phelps, (1994) confirmed the impact of oil shocks on unemployment rate, while Davis, 1986 confirmed the oil price changes impact in reducing the role of technology shocks in real business cycle models. Similarly, large research finds that oil price shocks have affected inflation (e.g., Hamilton, 1983, 1988, 1996, 2000; Hooker, 1996, 1999, 2002; Huntington, 1998; Kahn \& Hampton, 1990; Mork, 1989, 1994; Tatom, 1988). However, different impact may arise to each country due to some variables such as their sectoral structure, their relative position as oil importer or exporter or their differential tax composition. Thus, understanding the empirical relationship between oil prices and inflation rates is an important as most monetary authorities attempt to keep inflation under control. Knowledge of the inflationary effects of oil price increases will then assist monetary authorities to conduct policy to accommodate these shocks.

Sustainable oil price hike in the global market in the last decade permitted Algeria to improve its financial and macroeconomic indicators. As a result of enormous oil and gas revenues, Algeria currently runs a trade surplus. Real GDP has risen due to higher oil revenue and increased government expenditure. Although growth prospects are encouraging and economic indicators are satisfactory, revenue is subjected to variations in the price of oil and gas. Algeria is endowed with abundant hydrocarbon resources which make the country the largest oil producer in Africa behind Nigeria and Libya. Algeria has the 15th largest oil reserve (12.2 thousand million barrels at the end 2010) (BP Statistical Review, 2011). Unluckily, the Algerian economy is faced by the syndrome commonly referred to as the "resource curse", (Auty, 1993). Algeria is heavily dependent on oil and gas and the energy sector has long been the backbone of the Algerian economy. This sector alone accounts for roughly 45.7\% of GDP, $60 \%$ of budget revenues and over $98 \%$ of export earnings in 2006. Much of the oil revenue has been reinvested in economic development projects (highways, buildings, subways, railways, etc.) as part of a five-year plan 2010/2014. The public authority has relied on a US \$286 billion over five years. This is supposed to bring growth to $4.1 \%$ in 2011 after being at $2.4 \%$ in 2010 . Worth noting, economic growth is paltry compared to the high public spending. Algeria public spending has reached a total of $\$ 200$ billion between 2004/2009. The question that arises is: 
does the increase in oil price and government revenue followed by high public spending promote economic growth in Algeria?

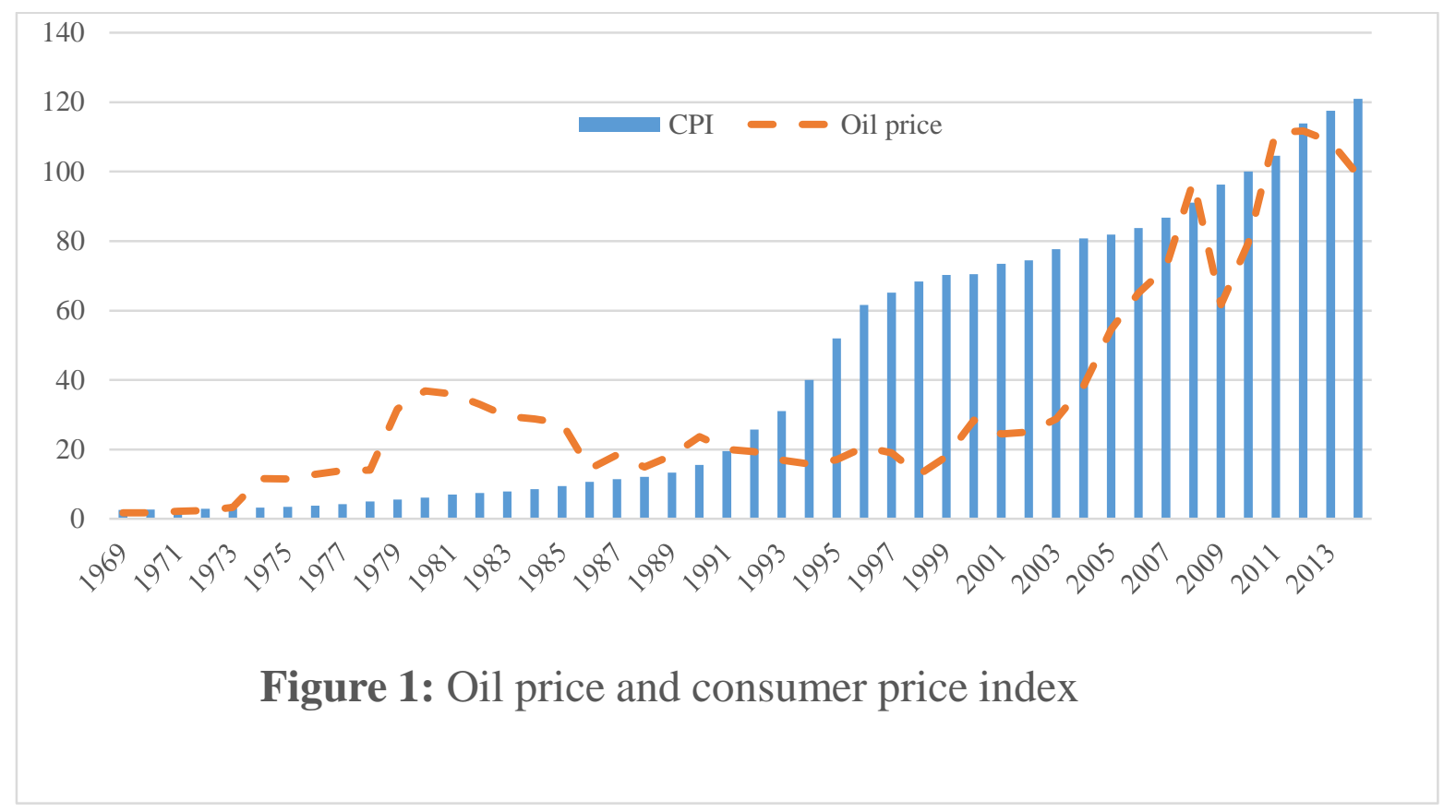

Source: World Bank (2015) and authors’ calculation

The recent sharp swings in the oil price have generated a great deal of concern especially on the effects of oil price on the inflation rate. To place this concern into perspectives, Figure 1 graphs the consumer price inflation as well as oil price inflation from 1969-2014. Despite lower oil price increment in later years, consumer price index (CPI) steadily increased over the years, especially since 1991.

Although the positive relation between oil price and inflation is well founded, current empirical evidence is far from being identical. For instance Hooker (2002), Leblanc and Chinn (2004), De Gregorio et al. (2007), Nakov and Pescatori (2007), and more recently Killian (2008) have confirmed a modest role of oil price fluctuations on consumer price index. Gauging the impact of oil price changes on US inflation rate, Hooker (2002) found a substantial direct contribution to core inflation before 1981 but little or no pass through since that time. By the same, in some Europe countries like France, Germany and the UK as well as US and Japan, Leblanc and Chinn (2004) confirmed a modest inflationary effect of oil price changes in the late 1990s. Unlike other studies that employed Philips Curve to determine asymmetries, Killian (2008) utilized counterfactual simulations for the G7 countries and confirmed that homogeneity cannot be ruled out. This finding is consist with other studies, Mork et al. (1994) confirmed that oil price shocks pass-through to inflation must be reckoned with a significant force in the shaping 
of business cycles of the leading market economies. Thus, oil price changes pass-through may differ from country to another. The different effect of oil price shocks on inflation may be tracked to several factors, including higher energy efficiency of production processes, the relevance of globalization and local market power in shaping price setting, as well as changes in the conduct of monetary policy. Furthermore, Cunado and de Gracia (2005) examined the inflationary impact of oil price shocks for several Asian economies and found some evidence of oil price shocks effect on inflation and growth.

These mixed findings have continued to thrill intense debate and paved ways for further research. For proper policy implication to conquer any emerging oil crisis, any analysis of the oil price pass-through to consumer price index must be conscious to various underlying domestic factors such as market power, and public regulations. Recognition of these factors may guide in policy strategies.

The effects of oil price increase and decrease to the inflation rate is well established, both theoretically and empirically. Facing a high oil price level, firms may either select to cut down production or translate it to higher level of output to consumers. In the same way, oil price reduction would lower the production cost and as a result the price level. However, oil price decrease may not lesser the price level of goods in a downward rigidity in nominal wages, or market suppliers that hold price levels up. From empirical front, many studies confirmed the existence of asymmetric relation among oil price shocks and inflation rate (Mork, 1989; Mory, 1993; and Hamilton, 1996). Additionally, other studies explored the existence of business cycle across economic activities, Sichel (1993) advocated that contractions tend to be steeper during economic deflation.

Given the high degree of dependence on oil revenues in Algeria, a robust analysis that considers the main transmission channels of oil price shocks on inflation rate is vital. This study is one of only a handful of studies that probe oil exporting country employing recent econometric approach. In this paper, we share in this stream of research by examining the descriptive role of oil price changes in CPI from Algeria's experience and perspectives. We employed a new econometric framework, namely the nonlinear autoregressive distributed lags (NARDL) model recently advanced by Shin et al. (2011). We content that, in light of the forgoing discussion, the approach is most appropriate since it allows for potential long-run and short-run asymmetries in the CPI - oil price relations. The rest of the paper is structured as follows. 
Section 2 highlights data and employed methodology. Results and discussion are presented in section 3. While section 4 concludes the study with main findings and recommended policies.

\section{Methodology}

\section{Model specification and estimation techniques}

The main purpose of our paper is to assess the effect of oil price changes in inflation level in Algeria from 1970 to 2014. It is in generally useful to consider an augmented Phillips curve with the following structure:

$$
C P I_{t}=\beta_{0}+\beta_{1} G D P_{t}+\beta_{2} O I L P_{t}+e_{t}
$$

Where $C P I$ is consumer price index, $G D P$ is real income expressed by gross domestic product to capture the effect of aggregate demand, OILP is oil price, $\beta_{i}$ is a vector of long run coefficients. Given the linear specification of equation (1), it will not be possible to capture asymmetric impact of oil price changes.

Following the empirical work of Cunado and Gracia (2005) and Ibrahim (2015), and accounting for asymmetries in the relationship between oil price and inflation, our model can be specified as follows:

$$
C P I_{t}=\theta_{0}+\theta_{1} G D P_{t}+\theta_{2} O I L P_{t}^{+}+\theta_{3} O I L P_{t}^{-}+\varepsilon_{t}
$$

Where $\theta_{i}$ is a vector of long run coefficients. The asymmetric impact of oil price is accounted for by including the positive changes $O I L P_{t}^{+}$and negative changes $O I L P_{t}^{-}$. Where the $O I L P_{t}^{+}$ and $O I L P_{t}^{-}$are partial sums of the positive and negative changes in $O I L P_{t}$, respectively:

$$
O I L P_{t}^{+}=\sum_{i=1}^{t} \Delta O I L P_{t}^{+}=\sum_{i=1}^{t} \max \left(O I L P_{i}, 0\right)
$$

and

$$
O I L P_{t}^{-}=\sum_{i=1}^{t} \Delta O I L P_{t}^{-}=\sum_{i=1}^{t} \min \left(O I L P_{i}, 0\right)
$$

From the above specification, the magnitude of the long run relationship between positive shocks in oil price and inflation is shown by $\theta_{2}$, whereas the long run relation between negative shocks in oil price and inflation is captured by $\theta_{3}$. Both coefficients are expected to have 
positive sign, but they are not anticipated to have similar magnitude, i.e. $\theta_{2}>\theta_{3}$, since positive changes in oil price will have higher effect on price level as compared to the inflation effect of negative changes in oil price (see Ibrahim, 2015).

Equation (2) can be written in an unrestricted error correction form as proposed by Pesaran et al. (2001) and Shin et al. (2011) as:

$$
\begin{aligned}
& \Delta C P I_{t}=\alpha_{0}+\alpha_{1} C P I_{t-1}+\alpha_{2} G D P_{t-1}+\alpha_{3} O I L P_{t-1}^{+}+\alpha_{4} O I L P_{t-1}^{-}+\sum_{i=1}^{q} \rho_{1 i} \Delta C P I_{t-i} \\
& +\sum_{i=0}^{p} \rho_{2 i} \Delta G D P_{t-i}+\sum_{i=0}^{m} \rho_{3 i} \Delta O I L P_{t-i}^{+}+\sum_{i=0}^{n} \rho_{4 i} \Delta O I L P_{t-i}^{-}+\mu_{t}
\end{aligned}
$$

Where all variables are explained above, $q, p, m$ and $n$ represent the lag order. From equation (3) the long run impact of positive and negative oil price changes on consumer price index are equivalent to $\theta_{2}=-\alpha_{3} / \alpha_{1}, \theta_{3}=-\alpha_{4} / \alpha_{1}$. The short run impact of positive oil price changes on inflation is shown by $\sum_{i=0}^{m} \rho_{3 i}$, while the short run effect of negative changes in oil price on inflation is measured by $\sum_{i=0}^{n} \rho_{4 i}$. One of the advantages of NARDL is that its enables us to capture asymmetries in the oil price - inflation relation not only in the long run but in the shortrun as well.

As initial step, we start our analysis by doing some pre-tests. First, we employ unit root to determine the order of integration of the variables. Although the autoregressive distributed lag model is appropriate for variables that have different order of integration, i.e. I(0) and I(1), but the estimator cannot capture I(2) type of series. Therefore, testing for unit root is very essential to avoid having I(2) series. To achieve that we use the Augmented Dickey Fuller (ADF) test and Kwiatkowski-Phillips-Schmidt-Shin (KPSS) test. Once the variables' order of integration is verified, we can estimate equation (3) using the ordinary least squares (OLS) method, and the lag length is chosen based on the information criterion SIC or general-to-specific. In addition, we test for the existence of long run relationship among variables, for linear and nonlinear specifications as in equation (1) and (2) respectively, using bounds testing for cointegration of Pesaran et al. (2001) and Shin et al. (2011) in an unrestricted error correction model as in equation (3). The null hypothesis of no cointegration, i.e. $\alpha_{1}=\alpha_{2}=\alpha_{3}=\alpha_{4}$ is tested against the alternative of cointegration, i.e. $\alpha_{1} \neq \alpha_{2} \neq \alpha_{3} \neq \alpha_{4}$ using F-test. As soon as the long run equilibrium relation exists among variables, we can estimate the long run asymmetric impact of oil price on inflation. The short run asymmetric impact of oil price on 
inflation is also assessed by deriving the cumulative dynamic multiplier of a one percent change in $O I L P_{t-1}^{+}$and $O I L P_{t-1}^{-}$, respectively as:

$d m_{l}^{+}=\sum_{j=0}^{l} \frac{\partial C P I_{t+j}}{\partial O I L P_{t-1}^{+}}, d m_{l}^{-}=\sum_{j=0}^{l} \frac{\partial C P I_{t+j}}{\partial O I L P_{t-1}^{-}}, \quad l=0,1,2, \ldots$

Note that as $l \rightarrow \infty, d m_{l}^{+} \rightarrow \theta_{2}$, and $d m_{l}^{-} \rightarrow \theta_{3}$.

The data

In our analysis, we make use of three macroeconomic variables: real GDP (GDP), consumer price index (CPI), and oil price (OILP) where oil price is expressed in \$US. This study used annual data from 1970-2014. While data were retrieved from World Bank Indicators. In our analysis, we make use of asymmetric oil price changes in where we distinguish between positive oil price changes $\left(\mathrm{OILP}^{+}\right.$) and negative oil price changes (OILP ${ }^{-}$). Many studies advocated the impact of oil price on inflation rate such as Mork, (1989); Mory, (1993); and Hamilton, (1996), also Mork (1994) confirmed the inflationary effect of oil price changes on inflation rate. Moreover, the relationship between oil price shocks and GDP growth is well established. For instance, Rasche and Tatom (1981), Darby (1982), Hamilton (1983), Burbidge and Harrison (1984), and Gisser and Goodwin (1986) confirmed linear relationship among GDP and oil price. More recently, Hamilton (2003), R Jiménez-Rodríguez (2004), and R Jiménez-Rodríguez and M. Sánchez (2005) found evidence of a non-linear relationship between the two variables.

\section{Empirical findings and discussion}

First, we started the analysis by conducting unit root test for the variables at level by including constant and time trend, as well as including only constant at first difference using ADF and KPSS tests. The findings are shown in Table 1. The result of ADF test confirms that the GDP and oil price are stationary after they converted to first difference, indicating that the variables are I(1), whereas it reveals that the series CPI contains unit root at level and first difference. Most importantly, the findings of KPSS test, which have more power compared to ADF test, appears to support the stationarity of the three variables at first difference, and thus all variables are $\mathrm{I}(1)$.

In view of that, we perform the cointegration test for linear and nonlinear specifications. The results of the bounds test are presented in Table 2. From the table we can see that there is no evidence of cointegration when the linear form is specified, since the F-statistic 3.819 is less 
than the lower critical bound. However, the long run relation exists when the model is specified in a nonlinear fashion, and the F-statistic 7.008 is greater than the upper critical bound at 5\%. These findings indicate that any wrong specification may lead to misleading conclusion regarding whether the variables move together in the long run or not.

Table 1 ADF and KPSS unit root tests

\begin{tabular}{llllll}
\hline \multirow{2}{*}{ Variable } & \multicolumn{2}{l}{ Level } & & & \multicolumn{2}{l}{ First difference } \\
\cline { 2 - 3 } \cline { 5 - 6 } & ADF & KPSS & & ADF & KPSS \\
\hline CPI & -1.923 & $0.140^{*}$ & -2.059 & 0.183 \\
GDP & -2.115 & $0.572^{* * *}$ & & $-4.188^{* * *}$ & 0.177 \\
OILP & -2.089 & $1.792^{* * *}$ & & $-6.016^{* * *}$ & 0.146
\end{tabular}

Note: *** and * denote significant at $1 \%$ and $10 \%$, respectively. The constant and time trend are included in level, but time trend is removed in first difference equations. The optimal lag order is selected based on SIC in the ADF test equation.

Table 2. Bounds test for linear/nonlinear cointegration

\begin{tabular}{lllll}
\hline Model specification & F-statistics & lower bound & upper bound & Conclusion \\
\hline Linear & 3.819 & 4.267 & 5.473 & No Cointegration \\
Nonlinear & 7.008 & 3.710 & 5.018 & Cointegration
\end{tabular}

Note: the critical values are from Narayan (2005) case III 5\% significance level. The optimal lag order based on SIC.

Applying general-to-specific procedure, we estimate the nonlinear model shown in equation (3) and the results are shown in Table 3. The model enables us to assess the inflation dynamic and its response to real GDP, positive and negative changes in oil price. Before estimating the long run model and making inferences, we perform some diagnostic test to assess the adequacy of the dynamic model. The $\mathrm{R}^{2}$ value is about 0.84 , which shows high power of the independent variables in explaining the changes of the dependent variable. Moreover, the serial correlation LM test reveals the absence of autocorrelation in the residuals. Similarly, the autoregressive conditional heteroskedasticity ARCH shows that the residuals have constant variance over time. In addition, Jarque-Bera or normality and Ramsey RESET tests indicate that the error tends to follow normal distribution, and the model is correctly specified, respectively. Furthermore, the stability of the model is tested by conducting CUSUM and CUSUM of squares tests as shown in Figure 2. Both tests reveal the stability of the model coefficients' 
since the estimated model lies within the 5\% significance line for CUSUM and CUSUM of squares tests.

Table 3. Nonlinear ARDL results

\begin{tabular}{|c|c|}
\hline Variable & Coefficient \\
\hline Constant & $0.089 * * \quad[0.035]$ \\
\hline CPI(-1) & $-0.105 * * *[0.036]$ \\
\hline $\operatorname{GDP}(-1)$ & $0.007 * * \quad[0.003]$ \\
\hline $\operatorname{OILP}^{+}(-1)$ & $0.029 * * \quad[0.012]$ \\
\hline $\operatorname{OILP}^{-}(-1)$ & $-0.0004 \quad[0.029]$ \\
\hline DCPI(-1) & $0.566 * * *[0.108]$ \\
\hline DGDP & $0.024 * * *[0.006]$ \\
\hline DGDP(-1) & $0.014 * * \quad[0.006]$ \\
\hline $\operatorname{DOILP}^{+}(-2)$ & $-0.061 * \quad[0.035]$ \\
\hline OILP $^{-}$ & [0.041] \\
\hline $\mathrm{R}^{2}$ & 0.837 \\
\hline Serial correlation LM(1) & 0.696 \\
\hline Serial correlation LM(2) & 0.247 \\
\hline Heteroskedasticity ARCH(1) & 0.912 \\
\hline Heteroskedasticity ARCH(2) & 0.309 \\
\hline Normality Jarque-Bera & 0.924 \\
\hline Ramsey RESET & 0.102 \\
\hline
\end{tabular}

Note: ${ }^{* * *},{ }^{* *}$ and $*$ denote significant at $1 \%, 5 \%$ and $10 \%$, respectively. The lag order is between ( ), the standard errors are between [ ]. 


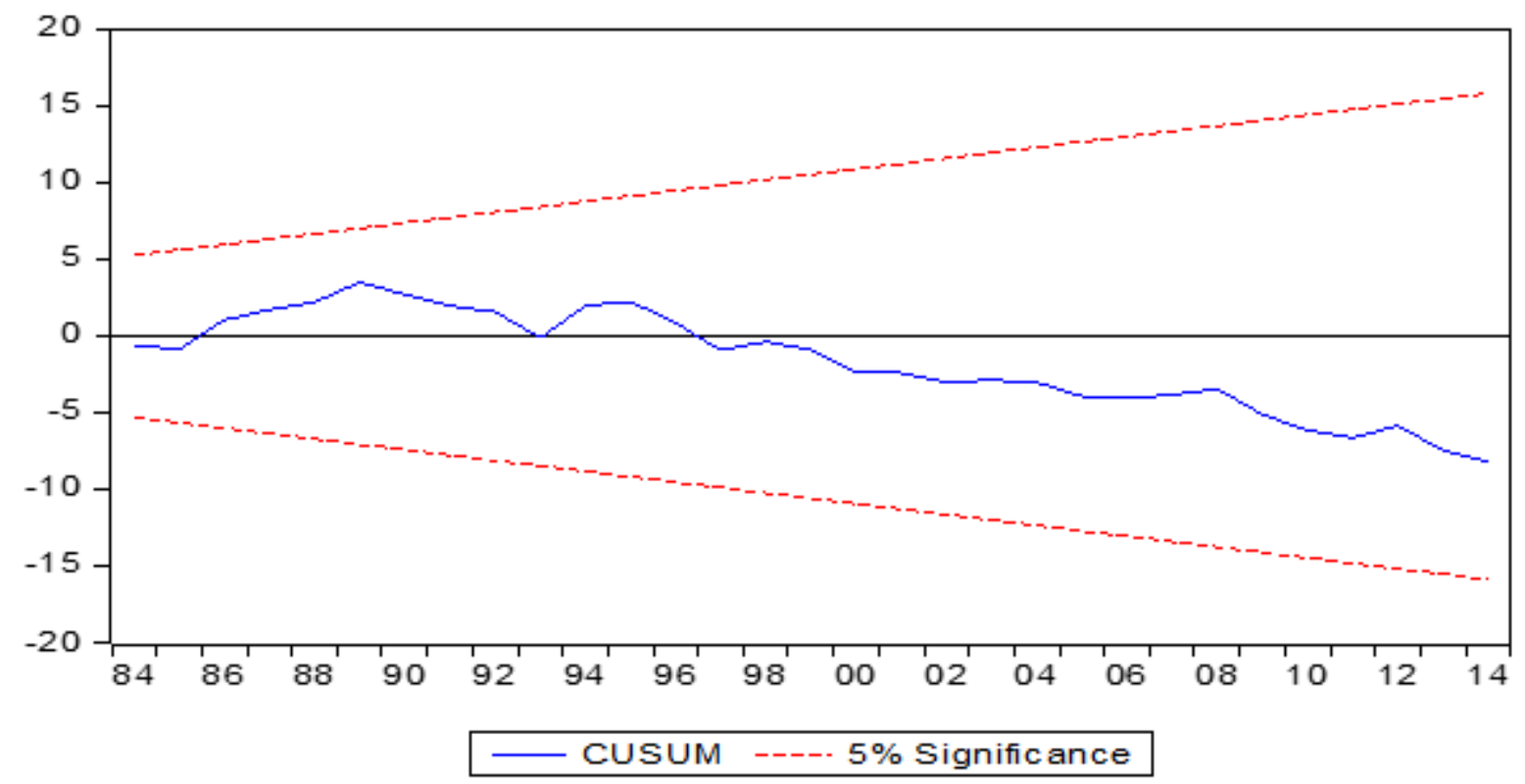

(A) CUSUM test

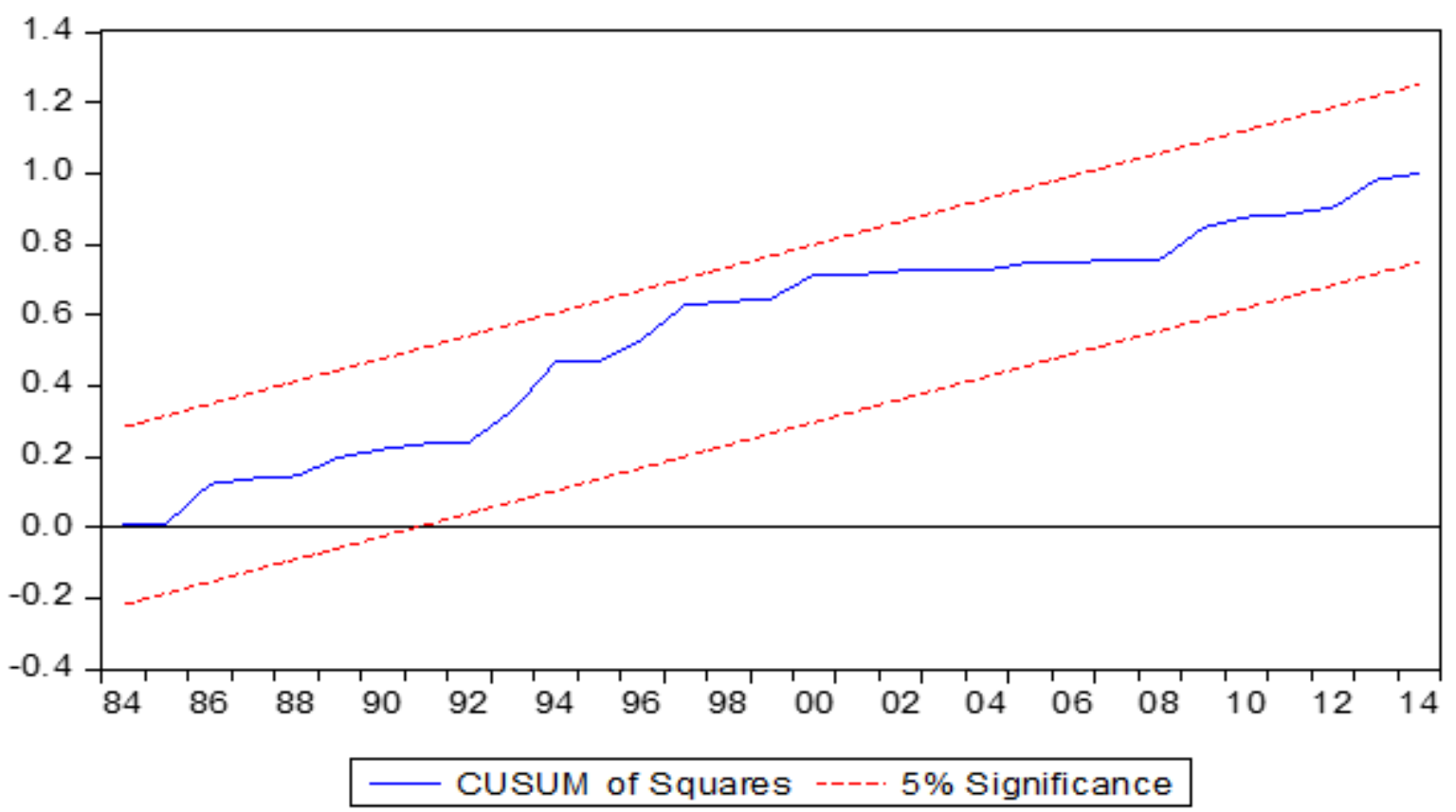

(B) CUSUM of Squares test

Figure 2. Model stability

Table 4 presents the long run coefficients computed from the dynamic model shown in Table 3. The results reveal the long run impact of real income on consumer price inflation to be positive and statistically significant at $1 \%$. In particular, it suggests that $10 \%$ increase in real GDP leads to $0.70 \%$ increase in consumer price inflation. One of the important findings emerge 
from this study is that oil price is found to have an asymmetric impact on consumer price inflation. The inflation effect of positive changes in oil price appears to be positive and statistically significant at $5 \%$, whereas the negative changes in oil price is found to be insignificant. Similar to various studies (see, Cunado and Gracia, 2005; and Ibrahim, 2015), the pass-through effect of oil price to the domestic inflation seems to be incomplete. The findings obtained by our study suggest that $1 \%$ increase in oil price will lead to approximately $0.27 \%$ increase in consumer price level.

Although higher oil price in Algeria would increase exports revenues and which may rise GDP level, consumer price inflation follows as well. Since oil products is a main input of many commodities and goods in the production process, productions are highly connected with oil and refined oil prices. The increase in oil price in the global market not only benefit the Algerian economy through higher exports revenue, but harm the economy through higher prices of many commodities and goods as well, which are not output of the Algerian economy but exported for local demand. It would be beneficial for Algeria to produce its main required commodities and goods since oil products and gas is low and subsidised in the country. However, this suggestion may not be effective without high technology adoption in order to meet standard quality and demanded quantity.

Regarding the short run impact of oil price changes, from the results in Table 3 it can be seen that oil price increases affect inflation only after two lag periods, whereas there is no significant change in consumer price inflation is observed due to negative changes in oil price. On the other hand, the real income affects inflation contemporaneously as well as with one lag period. Further, the inflation level shows some persistence since the lagged-dependent variable is positive and significant.

Table 4. Long-run model

\begin{tabular}{ll}
\hline Variable & Coefficient \\
\hline Constant & $0.841^{* * *}[0.296]$ \\
GDP & $0.070^{* * *}[0.018]$ \\
OILP $^{+}$ & $0.272^{* *}[0.110]$ \\
OILP $^{-}$ & $-0.004 \quad[0.280]$ \\
\hline
\end{tabular}

Note: $* * *$ and ${ }^{* *}$ denote significant at $1 \%$ and $5 \%$, respectively. The standard errors are between [ ]. 
Since the oil price decrease is insignificant in both short run and long run, we only compute the dynamic multiplier of oil price increase on consumer price inflation as shown in Figure 3. It is worth mentioning that increase in oil price takes about 6 to 7 years to be fully transferred to the domestic price level and converges to the long run coefficient 0.272.

Insignificance of oil price reduction on CPI contrary to oil price increase is luckily a result of market power intervention to hold prices up by suppliers. Hence, absence of oil price reduction impact of CPI advocate the conclusion that the market power does play a significant role (Karantininis et al. 2011a, b). In this regard, an intervention in the economy in order to favour competition and break down monopolistic is the right action.

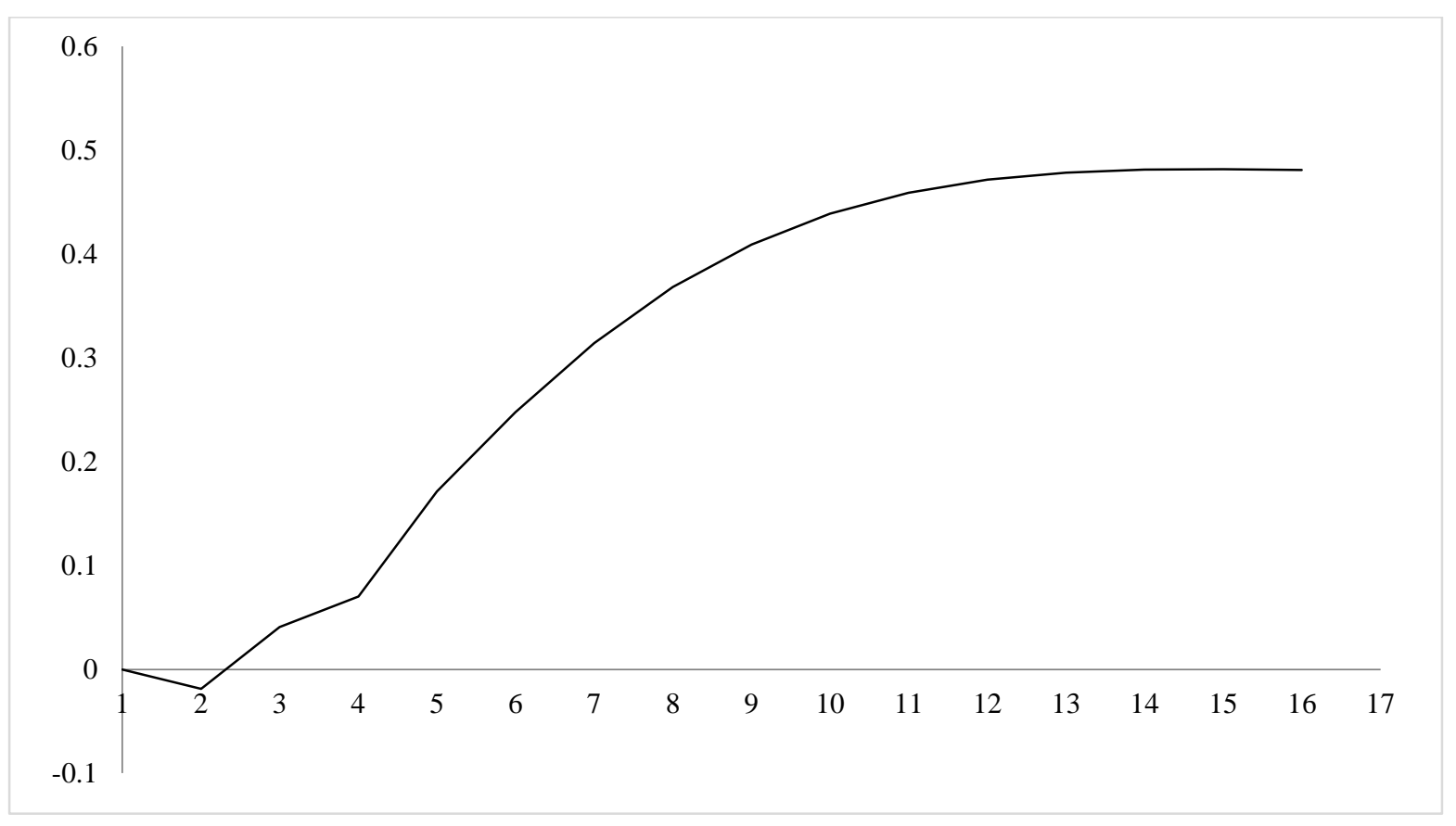

Figure 3. Multiplier impact of oil price increase.

\section{Conclusion}

Sharp increase in oil price since 2004 has brought attention from policymakers and macroeconomists alike and led to much research and discussion on the inflationary effect of oil price increase on macroeconomic indices including consumer price index. Moreover, the sharp decrease in oil price since the last year caught the attention of many oil exporting countries in MENA region including Algeria. Hence, understanding the empirical linkage between oil prices and inflation rates is then essential as most monetary authorities attempt to 
keep inflation under control. Knowledge about the inflationary effects of oil price increases will then assist monetary authorities to adopt appropriate policy to accommodate these shocks.

This paper analyse the impact of oil price changes on CPI, and to do so we adopt a nonlinear ARDL model for the analysis to capture both long-run and short-run asymmetric relations between CPI and oil prices. Estimated results confirm the existence of both long-run and shortrun asymmetry behaviour of CPI. Precisely, in the long-run, oil price increase tend to increase inflation level in Algeria. However, oil price decrease seems to be unrelated to inflation level. Similarity, in the short-run, only oil price increase seems to increase inflation in Algeria.

From a policy perspective, over the years, various approaches have been adopted by the government of Algeria to address rising consumer price inflation. These include financial support to small enterprises and enhancement of agricultural productivity through high technology adoption. However, policy attention should be directed to containing market power and, to be more effective, should cover all suppliers (importers, wholesalers and retailers). Moreover, adoption of productive technology in the local market is recommended to benefit from low price oil products, and thus achieve higher surplus in balance of payments through imports reduction. 


\section{References}

Auty, R.M., (1993). Sustaining Development in Resources Economies: The Source Curse Thesis. Routledge, London and New York.

British Petroleum, (2011). BP Statistical Review of World Energy, June 2011.

Burbidge, J., \& Harrison, A. (1984). Testing for the effects of oil-price rises using vector autoregressions. International Economic Review, 459-484.

Caruth, A. A., Hooker, M. A., \& Oswald, A. J. (1998). Unemployment equilibria and input prices: Theory and evidence from the United States. Review of Economics and Statistic, $80,621-628$.

Cunado J, de Gracia FP (2005) Oil prices, economic activity and inflation: evidence from some Asian countries. Q Rev Econ Finance 45(1):65-83

Darby, M. R. (1982). The price of oil and world inflation and recession. The American Economic Review, 738-751.

Davis, S. J., \& Haltiwanger, J. (2001). Sectoral job creation and destruction responses to oil price changes. Journal of Monetary Economics, 48, 465-512.

Davis, S. J. (1986). Allocative disturbances and temporal asymmetry in labor market fluctuations [mimeo]. University of Chicago.

De Gregorio, J., Landerretche, O., Neilson, C., (2007). Another pass-through bites the dust? Oil prices and inflation. Working Papers Central Bank of Chile, p. 417.

Gisser, M., \& Goodwin, T. H. (1986). Crude oil and the macroeconomy: Tests of some popular notions: Note. Journal of Money, Credit and Banking, 95-103.

Hamilton, J. (1983). Oil and the macroeconomy since World War II. Journal of Political Economy, 91, 593- 617.

Hamilton, J. (1988). A neoclassical model of unemployment and the business cycle. Journal of Political Economy, 96, 593-617.

Hamilton, J. (1996). This is what happened to the oil price-macroeconomy relationship? 
Journal of Monetary Economy, 38, 215-220.

Hamilton, J. (2000). What is an oil shock? (NBER working paper 7755).

Hamilton, J. D. (2003). What is an oil shock?. Journal of econometrics, 113(2), 363-398.

Hooker, M. (1996). What happened to the oil price-macroeconomy relationship? Journal of Monetary Economics, 38, 195-213.

Hooker, M. (1999). Oil and the macroeconomy revisited [mimeo]. Federal Reserve Board. Hooker, M. (2002). Are oil shocks inflationary? Asymmetric and nonlinear specifications versus change in regime. Journal of Money, Credit and Banking, 34, 540-561.

Huntington, H. (1998). Crude oil prices and U.S. economic performance: Where does the asymmetry reside? Energy Journal, 19, 107-132.

Ibrahim, Mansor H. "Oil and food prices in Malaysia: a nonlinear ARDL analysis." Agricultural and Food Economics 3.1 (2015): 1-14.

Jiménez-Rodríguez, R. (2004) Oil price shocks: testing for non-linearity, Center for Studies in Economics and Finance Working Paper No. 115.

Jiménez-Rodríguez, Rebeca, and Marcelo Sánchez. "Oil price shocks and real GDP growth: empirical evidence for some OECD countries." Applied economics 37.2 (2005): 201228.

Kahn, G., \& Hampton, R. (1990). Possible monetary policy responses to the Iraqui oil shock.

Federal Reserve Bank of Kansas City Economic Review, 2, 19-32.

Karantininis K, Katrakylidis K, Persson M (2011a) Price Transmission in the Swedish Pork Chain: Asymmetric Non Linear ARDL. EAAE 2011 Congress, Zurich, Switzerland

Karantininis K, Kostas K, Persson M (2011b) Price transmission in the Swedish pork chain: Asymmetric nonlinear ARDL., Paper presented at the EAAE 2011 Congress: Challenges and Uncertainty, September 2, 2011, Zurich, Switzerland

Killian, L., 2008. A comparison of the effects of exogenous oil supply shocks on output and inflation in the G7countries.Journal of the European Economic Association 6(1), 78121. 
Mork, K. A., Olsen, Ø., \& Mysen, H. T. (1994). Macroeconomic responses to oil price increases and decreases in seven OECD countries. The Energy Journal, 19-35.

Mork, K. (1989). Oil and the macroeconomy when prices go up and down: An extension of Hamilton’s results. Journal of Political Economy, 97, 740-744.

Mork, K. (1994). Business cycles and the oil market. Energy Journal, 15, 15-38.

Mory, J. F. (1993). Oil prices and economic activity: is the relationship symmetric? The Energy Journal, 151-161.

Nakov, A., Pescatori, A., 2007. Oil and the great moderation. Working Paper 0735. Banco de España.

LeBlanc, M., \& Chinn, M. D. (2004). Do high oil prices presage inflation? The evidence from G-5 countries. UC Santa Cruz Economics Working Paper, (561), 04-04.

Pesaran, M. H., Shin, Y., \& Smith, R. J. (2001). Bounds testing approaches to the analysis of level relationships. Journal of applied econometrics, 16(3), 289-326.

Phelps, E. S. (1994). Structural slumps. Cambridge: Harvard University Press.

Rasche, R. H., \& Tatom, J. A. (1981, December). Energy price shocks, aggregate supply and monetary policy: the theory and the international evidence. In Carnegie-Rochester Conference Series on Public Policy (Vol. 14, pp. 9-93). North-Holland.

Tatom, J. (1988). Are the macroeconomic effects of oil price changes symmetric? Carnegie Rochester Conference Series on Public Policy, 28, 325-368.

Shin Y, Yu B, Greenwood-Nimmo M (2011) Modelling Asymmetric Cointegration and Dynamic Multiplier in a Nonlinear ARDL Framework, Mimeo

Sichel, D. E. (1993). Business cycle asymmetry: a deeper look. Economic Inquiry, 31(2), 224-236. 